THE

\title{
Food Value of Margarin
} or Oleomargarine

\author{
BY J. S. ABBOTT
}

Secretary, Institute of Margarin Manufacturers WASHINGTON, D. C.

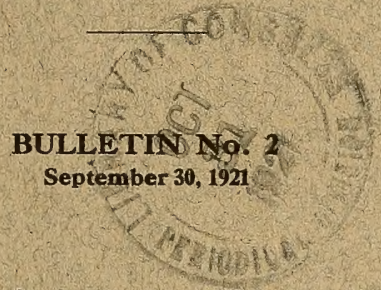

The object of this bulletin is to encourage a correct understanding by the public of Margarin or Oleomargarine

$$
\text { ৫) }
$$

ISSUED BY THE

\section{INSTITUTE OF MARGARIN MANUFACTURERS}

$$
\begin{aligned}
& 1212 \text { MUNSEY BUILDING } \\
& \text { WASHINGTON, D. C. }
\end{aligned}
$$

For further information, address this office 



\title{
THE
}

\section{Food Value of Margarin or Oleomargarine}

\author{
BY J.' S. ABBOTT \\ Secretary, Institute of Margarin Manufacturers \\ WASHINGTON, D. G.
}

BULLETIN No. 2

September 30, 1921

The object of this bulletin is to encourage a correct understanding by the public of Margarin or Oleomargarine

\section{ధ}

ISSUED BY THE

\section{INSTITUTE OF MARGARIN MANUFAGTURERS}

1212 MUNSEY BUILDING

WASHINGTON, D. C.

For further information, address this office 


$$
\begin{array}{r}
\text { SFa68 } \\
\text { I5 }
\end{array}
$$




\title{
- The Food Value of Margarin or Oleomargarine
}

\author{
By J. S. ABBOTT \\ Secretary, Institute of Margarin Manufacturers \\ Washington, D. C.
}

The importance of fat in the human dietary has been a matter of common knowledge for ages, but this fact was never greatly emphasized on a world scale until near the close of the war. The sources of the edible fats of different countries differ somewhat. Until recently, the people of this country obtained their fats, as fats, almost exclusively from cattle, hogs, and sheep in the form of butter, lard, and "drippings." Olive oil has been a common foodstuff for centuries in many countries of the old world. Cocoanut oil is eaten in large quantities in the tropical countries in which cocoanuts are grown. Cottonseed oil, peanut oil, corn oil, and many other vegetable oils have recently become common articles of food in this country, either as cooking fats or as salad oils. Margarin is a combination of edible fats and milk, skim milk, or cream.

The following statements appear in Bulletin 469 of the U. S. Department of Agriculture:

"A discussion of animal fats would not be complete without some mention of oleomargarine, called 'margarin' in Europe. The principal fats used in its manufacture in the United States are oleo oil, neutral lard (that is, a specially rendered lard), and cottonseed and other oils. All these ingredients must be pure and prepared with 
care in order that none of them shall have any marked taste or odor. These are mixed in such proportions as will give the final product a melting point very near that of butter. After being thoroughly mixed the fats are churned with a small quantity of milk and sometimes cream, the proportions of these used depending upon the quality of the product desired. In the preparation of high-grade oleomargarine varying quantities of butter are also added. The resulting product is then washed, salted, and worked as in ordinary butter-making processes. Oleomargarine is not used as extensively in this country as in Europe, where it serves both for table and culinary purposes."

The principal fats and oils used in the manufacture of margarin at the present time are oleo oil, "neutral," peanut oil, cottonseed oil, and cocoanut oil.

The value of any fat or oil as food depends upon its digestibility, energy value, looks, taste, and texture. In recent years fats and oils, as well as many other foodstuffs, have been declared to contain certain food accessory substances, called vitamines, which are believed to play an important rôle in nutrition.

\section{Digestibility.}

The digestibility of some of the common edible fats, according to Bulletins 310,505 , and 613 of the U. S. Department of Agriculture, is as follows:

Per cent.

Per cent.

\begin{tabular}{|c|c|}
\hline Margarin $\ldots \ldots \ldots \ldots \ldots \ldots 97.55$ & Oleo oil............. 96.8 \\
\hline Butter ............ 97 & "Neutral"............ 97. \\
\hline Cocoanut oil......... 97.9 & Pènut oil.......... 98.3 \\
\hline Cottonseed oil........ 97.8 & \\
\hline
\end{tabular}




\section{Energy Value.}

The value of a fat as a food is commonly expressed in terms of its energy value, or calories. For the fats above, according to Bulletin 469 of the U. S. Department of Agriculture, they are as follows:

Calories.

Calories.

1 pound margarin....... 3,500

1 pound oleo oil........4, 4,080

1 pound butter......... 3,490

1 pound "Neutral"....... 4,080

1 pound cocoanut oil..... 4,080

1 pound peanut oil...... 4,080

1 pound cottonseed oil.... 4,080

It is clear, therefore, that margarin is the equal of butter, in so far as their digestibilities and energy values are concerned. This fact was made known a long time ago by such famous nutrition experts as Luhrig, Barterelli, Hulbgren, Landergren, and Halliburton and Drummond. ${ }^{1}$ Taylor very recently confirmed it. ${ }^{2}$

\section{Taste, Looks, and Texture.}

The taste, looks, and texture of foodstuffs are just as important food values as digestibility and energy. There are no units of measurements of these values. As they occur in high grades of butter, they have been acceptable to consumers for centuries. Margarin manufacturers, therefore, have striven, and with great success, to incorporate the same properties into margarin. So successfully have they been that it would take an expert taster to tell the difference between good butter and margarin at the factories or as long as they have been properly kept. This fact can be appreciated when it is remembered that the chief difference in the composition of butter and margarin is that one contains milk fat and the other contains milk fat 
and animal or vegetable fats, or a mixture of two or more of them.

Fats themselves have very little taste or flavor. On this point Holmes and Lang ${ }^{3}$ make the following statement:

"The flavors and odors of fats are probably due to the presence in them of small amounts of difficultly removable substances rather than to specific properties of the pure fats themselves, in view of the fact that flavors and odors become much less noticeable the more completely the fats are purified. The characteristic flavor of butter, for example, is due to the absorption by the fat of the substances formed in the fermentation of milk and cream by lactic acid and bacteria and to the presence of small particles of the curd."

'The flavor of margarin is likewise due to "the absorption by the fat of the substances formed in the fermentation of milk and cream by lactic acid and bacteria and to the presence of small particles of the curd." Each type of margarin made in this country is made by churning fats and oils in ripened milk or cream and gets its flavor from them. The color and texture likewise simulate those of good uncolored butter. When margarin is colored it looks like colored butter.

In consideration of the digestibility, energy value, taste, looks, and texture of good butter and margarin, it is apparent that the one may be substituted for the other as a table fat or as a culinary fat.

In consideration of cleanliness and wholesomeness, there are possibilities of wide differences. Nearly all of the margarin made in the United States is made under the constant supervision of Federal Government inspectors, and therefore complies with all of the hygienic requirements of the Government. There is no such supervision over the manufacture of butter. 


\section{Fat-Soluble Vitamines.}

Vitamines have been divided into two classes, viz., those that are freely soluble in fats and those that are freely soluble in water. Fat-soluble vitamines are also somewhat soluble in water. The fat-soluble vitamines are commonly spoken of as fat-soluble A.

Just what foodstuffs contain appreciable quantities of the fat-soluble vitamines has been the subject of tedious investigations by nutrition experts for about ten years. A compilation of all the work done on this problem was made and reported in July, 1919, by a committee appointed jointly by the Lister Institute of Preventive Medicine and the Medical Research Committee of National Health Insurance, England. ${ }^{4}$ This authority makes the following statement concerning the source and quantity of fat-soluble vitamines in our various foodstuffs:

"The primary sources of fat-soluble A are found in the green leaves of plants and the embryos of certain seeds. The former appear to be the richer source, but very few quantitative data upon the distribution of the substance have yet been obtained. It is, therefore, difficult to attach a definite value to any individual foodstuff as a source of fat-soluble A. This is particularly true in the case of the foodstuffs of animal origin, as their value as sources of that factor is in all probability directly determined by the nature of the diet which the animal has previously received. Thus, the milk yielded by a cow which has for some time past been receiving a diet deficient in fat-soluble A will, without doubt, sooner or later show the same deficiency.

"The following tabulation of the chief foodstuffs has been made with the object of illustrating the distribution of the fat-soluble A factor: 


\section{Foodstuffs That Contain Fat-Soluble Vitamines.}

Butter.

Cream.

Margarin prepared from animal fats other than lard.

Nut butter.

Mutton and beef fat.

Heart.

Brain.

Sweetbreads.

Linseed.

Linseed cake (after expulsion of oil).

Peas.

Kidney beans.

Soy-beans.

Cabbage (fresh).

Cabbage (dried).

Lettuce.

Spinach.

Carrots (fresh).

Carrots (dried).
Cod-liver oil and other fish liver oils.

Herring oil, salmon, or cod oil. Liver.

Kidneys.

Onions.

Potatoes.

"Fat" fish, as herring, salmon.

Fish roe.

Wheat embryo.

Maize embryo.

Rice embryo and bran (i. e., socalled rice polishings).

Whole-meal bread.

Millet.

Bananas.

Nuts (walnuts).

Cheese (prepared from whole milk).

Eggs (yolk).

Eggs (dried).

It will be noted in the table above that the Committee, by inference, stated that margarin made from lard does not contain the fat-soluble vitamine. Margarins are not made of lard in this country.

The fat-soluble vitamine content of animal and vegetable oils has been the subject of more careful investigations. Many of these fats and oils hitherto reported as deficient in these bodies have been found to be fairly rich in them. Daniels and Loughlin ${ }^{5}$ found that rats fed on a ration from which all fatsoluble A had been removed except what was in the lard of the ration "grew normally, reproduced, and reared their young." 
They got the same results with cottonseed oil. Both of these fats are used in the manufacture of margarins.

Just as lard and cottonseed oil have recently been found to contain quite a plenty of fat-soluble A to promote growth, reproduction, and the rearing of the young of animals, just so it may be that all other fats and oils hitherto reported to be deficient in it are quite efficient in this respect.

The same kind of fat or oil at different times and under varying circumstances may contain different quantities of fatsoluble vitamines. They are not present in some grades of butter. Steenbock ${ }^{8}$ says the vitamine content of butter varies with the breed and feed of the cow. He reported one experiment in which the butter fat of a cow fed exclusively on alfalfa hay did not contain any fat-soluble vitamines. ${ }^{7}$

Only a very few researches have been carried on to determine the fat-soluble vitamine content of margarins. The milk and cream and the fats and oils used in the manufacture of margarin contain these vitamines. $4,5,8,9$ The processes of the manufacture of margarin do not affect them. All types of margarins contain appreciable quantities of fat-soluble vitamines.

From the foregoing facts, it is clear that there is not any essential difference between butter and margarin with respect to these food-accessory substances. Butter and margarin are as much alike in digestibility, energy value, taste, looks, texture, and vitamines as it is possible for two products to be alike and not be the same thing.

As was shown above, fat-soluble vitamines occur in numerous foodstuffs. Hence the chance of a failure to get a sufficient quantity of them in our diet is exceedingly small. More important than this fact, however, is the fact that animals 
have the power to store up in their systems enough fat-soluble vitamines to carry them over long periods of time without an additional supply. "Osborne and Mendel fed rats dried spinach, which is rich in fat-soluble vitamines, to the extent of 5 per cent of the diet, as the only source of fat-soluble vitamines, for 87 and 83 days; then substituted the spinach by yeast, which is free from the fat-soluble vitamine. The rats continued to thrive for 93 days and 97 days longer; that is, they had stored up enough of the fat-soluble vitamine from the spinach to last them through the long period of deprivation." 10 The same provision of nature is seen in the bearing and rearing of the young of animals. The natural breeding time of cattle, for example, is in the spring time. The young are born in the spring time when the mother animal has a chance to get an abundant supply of green grass and leafy vegetation, which, as has been noted, are the original sources of vitamines. By winter time these animals have stored up sufficient vitamines to carry them through the winter months, when their feed is deficient, if not entirely lacking, in fat-soluble vitamines.

In view of the foregoing facts, it is not at all strange that Katherine Blunt, ${ }^{10}$ in her closing remarks on the Present Status of Vitamines, made the following comment:

"It is difficult to say what is the importance to the average individual of giving thought to these three vitamines in choosing the diet." 


\section{References.}

1. Halliburton and Drummond, The Journal of Physiology, September, 1917.

2. Dr. A. E. Taylor, School of Medicine, University of Pennsylvania. The Saturday Evening Post, March 5, 1921.

3. A. D. Holmes and H. L. Lang, Bulletin 469, U. S. Department of Agriculture.

4. Report on the Present State of Knowledge concerning Accessory Food Factors (Vitamines), Medical Research Committee, National Health Insurance. Special Report Series No. 38, London, July, 1919.

5. Amy L. Daniels and Rosemary Loughlin, Department of Nutrition, Child Welfare Research Station, University of Iowa, Iowa City. Jourual of Biological Chemistry, Vol. 42, No. 3.

6. H. Steenbock, Laboratory of Agricultural Chemistry, University of Wisconsin. The Science Press, Vol. 50, p 352.

7. Journal of Biological Chemistry, September, 1918.

8. Proceedings of the Physiological Society, London, January 27, 1917 , p. VIII.

9. E. V. McCollum, Journal of Home Economics, May, 1917.

10. Katherine Blunt and Chi Che Wang, University of Chicago. The Journal of Home E'conomics, Vol. 12, No. 1. 



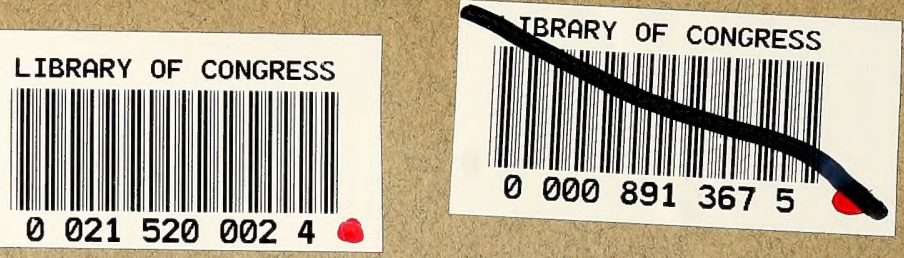